\title{
Editorial Foreword 77.4 (November 2018)
}

\section{Our Cover}

The cover photograph shows an expanse of yellow folded-paper boats covering the grassy plaza in front of Seoul City Hall a few weeks after the Sewol Ferry Disaster on April 16, 2014. In a maritime incident where deaths should have been avoidable, 304 people were killed in a ferry sinking, including 250 Danwon High School students. After it was later revealed that only one out of the ferry's forty-six lifeboats had been deployed-and that was to rescue not passengers but only the captain and ten crew members - the paper boats also underscored the demand for a full investigation by the victims' families and their advocates. Regarding the scene depicted in the photograph, officials from Seoul's city government authorized the creation of this public memorial, which included several tents lining the plaza where residents could offer their condolences and grieve among others. As people from all walks of life came to that downtown space, they would wait in line so that each visitor could place a white flower at a memorial altar, in keeping with tradition for modern Korean funerals. Mourners also expressed their sympathies with handwritten notes on the paper boats, including wishes for safe passage to the afterlife for the souls of those who had died. Under the white open-air tents, rows upon rows of cord were suspended for mourners to tie yellow ribbons, which also bore personal messages of grief, consolation, and apology. In addition to emblems of sympathy, the paper boats would come to be associated with criticism toward the Park Geun-hye government for its role in the disaster through a bungled response followed by an aggressive cover-up. Through such gestures of public mourning, both the yellow ribbons and folded-paper boats became integrated into a larger material culture of long-term dissent during the final three years of the Park era, as Nan Kim, who wrote this description, explores in her article in this issue. This photograph, taken by award-winning journalist Kim Cheol-soo, appeared in the Seoul-based online newspaper Voice of the People (민중의소리, www.vop.co.kr). Photo (C) 민중의소리, 2014.

\section{IN THIS ISSUE}

My ten years serving as editor of this publication came to an end on June 30, 2018, so this will be the last editorial foreword I write for the JAS. I am writing it rather than my successor, Vinayak Chaturvedi, because this issue is made up of exclusively, book reviews aside, pieces that were accepted before my term ended and his began. It is a particular pleasure to have this issue be my final one to introduce, due to the variety of articles in terms of geography, topics, approaches, and even styles of writing. I strove during my ten years to have as many issues as possible include this kind of diversity of essays, and wherever possible also temporal variation—something that this issue lacks, as all contributors 
focus on the present or the recent past. It may be fitting, though, given that an editor of a journal such as this one needs to make sure that specialties other than his or her own are well represented, that this issue is being introduced by a China scholar and historian, yet includes just a single contribution in Chinese studies and is made up primarily of articles by people whose main field is not history.

\section{Presidential Address}

The issue begins with Katherine A. Bowie's “Palimpsests of the Past: Oral History and the Art of Pointillism," a revised version of the presidential address she delivered at the springtime annual meeting of the Association for Asian Studies. It is made up of two parts: a broad survey of the varied ways that oral history has figured in work on different parts of Asia, and a case study of how interviews can be used to not just "fill gaps" but place important issues in novel perspective in a very specific Thai case. Like many of the best presidential addresses of the past, this means it has much to offer both specialists in the author's own field and people with very dissimilar interests. Given the growing importance of summertime "AAS-in-Asia" meetings for the Association, whose flagship journal this is, it is fitting that Bowie notes early on that her thinking on the topic was shaped by conversations she had at the organization's June 2017 gathering in Seoul.

\section{JaS at AAS: The Market, the Media, and the State in Asia II}

This is followed by a wide-ranging "JAS at AAS" forum, based per usual on a panel held at the springtime annual meeting, which was called "The Market, the Media, and the State in Asia II" - the numeral signifying that the panel was a sequel of sorts to one held nine months earlier in Seoul, another example of AAS-in-Asia and JAS synergy. It begins with a brief introduction by JennifER H. Munger, followed by the first of five presentations, "Watchdog Journalism in Japan Rebounds but Still Compromised," a long essay by JefF Kingston, a Tokyo-based scholar who writes regularly for both academic publications and newspapers. This is followed by two more articles by authors living in Asia: "Vietnamese Media Going Social: Connectivism, Collectivism, and Conservatism," whose author, Giang Nguyen-Thu, is the first contributor to the JAS to be serving on the faculty of a Vietnamese academic institution at the time of writing and publication; and "In Bangladesh: Direct Control of Media Trumps Fake News," whose author, K. Anis Ahmed, works in the country about which he is writing, also a place from which contributors to JAS have rarely, if ever, been based in the past. Finishing off the section are Aynne KoKas's "Platform Patrol: China, the United States, and the Global Battle for Data Security" and Tyrell Haberkorn's "Dictatorship, Monarchy, and Freedom of Expression in Thailand." The forum, which brings in the perspectives from fields ranging from cultural studies to political science, as well as journalism, highlights the diverse challenges that writers and states are grappling with in settings that are very different, but in each case see political shifts, technological shifts, or combinations of the two altering media environments. 


\section{Breaking Down Boundaries, Forging New Paths:}

\section{The Lining Memory of Nancy Abelmann}

This forum is followed by a very different cluster of essays, which are all by anthropologists (albeit one of them teaching in a history department) who have worked largely on South Korea. Titled "Breaking Down Boundaries, Forging New Paths: The Living Memory of Nancy Abelmann," it is inspired by the late anthropologist's work and her role as an influential figure in both Korean studies and Asian American studies. It begins with Eleana Kim and Jesook Song's self-explanatorily titled "Introduction: Reflections on Nancy Abelmann's Legacy," and includes a pair of case study essays that have close ties to that unusually creative scholar's diverse interests: JIYEON KANG's "Nancy Abelmann: Anthropologist, Citizen, and Thinker in/on the Global University," and "The Color of Dissent and a Vital Politics of Fragility in South Korea" by NAN KIM (the anthropologist based in a history department).

\section{Research Articles}

Closing out the front section of the issue, ahead of the usual mix of book reviews, are three research articles. The first of these is Ashraf Hoque and Lucia Michelutti's "Brushing with Organized Crime and Democracy: The Art of Making Do in South Asia." A work of comparative and cross-nation ethnography, which deals with both western Utttar Pradesh (in India) and Sylhet (in Bangladesh), it focuses on the strategies that a "category of young men often derogatively referred to as 'chamchas' (sycophants)" skilled in the "art of making do (jugaad)" employ in various situations, many of which involve crossing or blurring the line between legal and criminal social groups and other realms of activity.

Following this is another work on South Asia, in this case a single city within the region, titled "Inhabited Pasts: Monuments, Authority, and People in Delhi, 1912-1970s." Its author, Deвorah Sutton, presents the eponymous city as one that contains a "spectrum of monumental structures that appear variously to either exist in splendid isolation from the rush of everyday urban life or to peek out amidst a palimpsest of unplanned, urban fabric." She calls for "acknowledgement and acceptance of the hybridity of Delhi's monuments," saying that the city's built environment and its symbolic structures in particular offer "an opportunity to reorient understandings of urban heritage."

Closing the front section of the issue is "Clearing, 'Wasting,' and Regreening: An Environmental History of Bare Hills in Central Vietnam," a work by historian DAVID BIGGS. It shows well how our understanding of broad and familiar topics, such as the impact of war and the nature of colonialism, can be altered and deepened by close scrutiny of natural settings and the ways they are destroyed, protected, and transformed during periods of upheaval. It is valuable for what it contributes to Southeast Asian studies, but it also pairs well with the recent JAS Forum on Korean forests, and while reading it I was reminded of how many notable articles and clusters of essays published during my term, including one set of pieces on the Anthropocene and another on Amitav Ghosh's The Great Derangement: Climate Change and the Unthinkable, have dealt in 


\section{Editorial Foreword}

some fashion with environmental issues - a very fitting topic to claim increasing centrality in a publication such as this one during the decade lasting from July 2008 to June 2018 when I had the privilege to serve as its editor.

$-\mathrm{JNW}$ 